\title{
PENGARUH MEDIA PENDINGIN TERHADAP SIFAT MEKANIK DAN STRUKTUR MIKRO PLAT BAJA KARBON ASTM A-36
}

\author{
Sumiyanto \\ Abdunnaser \\ Dosen Tetap Program Studi Teknik Mesin \\ Fakultas Teknologi Industri - Institut Sains dan Teknologi Nasional \\ Jl. Moh Kahfi II, Jagakarsa, Jakarta 12640, Indonesia \\ E-mail: sumiyantoistn@yahoo.com - abdunnaser2000@yahoo.com
}

\begin{abstract}
Steel specification of ASTM, A-36, the strength can be improved through austenisation hot working. Workmanship of austenisation is done through warm-up of specimen at temperature $9000 \mathrm{C}$ during one hour clock, then made cool in coolant giving speed of different refrigeration. As coolant is refrigeration of lag in refrigeration stove in air-gap (air), dye oli, and dye water giving speed of highest refrigeration. Attempt result indicate that strength of steel from material early 423,9 MPa, after diaustenisation specimen, the strength increase becoming 474,9 MPa through air cooling, and 560,5 MPa through refrigeration dye water. Media cooler dye water, yield mechanical property is less good, because specimen manjadi is fragible (small elongation 6\%). Microstructure observation becomeed militant, phase which formed is ferrite as matrik and pearlite. Increasing of strength of call is caused by item formed by pearlite is higher distribution from at initial material. Specimen with refrigeration dye water, microstructure type which formed becoming change, phase which formed is ferrite of form of needle as matrik and martensite. This microstructure type give metal become brittle. Although the strength is highest (717,3 MPa).
\end{abstract}

Keywords: Microstructure, Diaustenisation

\section{PENDAHULUAN}

\section{Latar Belakang}

Pada perkembangan industri saat ini, logam merupakan salah satu material yang penggunaan nya sangat luas dan banyak digunakan dalam berbagai keperluan. Logam yang paling banyak digunakan salah satunya adalah baja. Baja merupakan bahan dasar yang sering digunakan untuk berbagai rekayasa teknik, salah satunya adalah plat baja karbon.

Proses tersebut dapat meningkatkan sifat mekanis yang lebih baik, untuk melihat kondisi ini maka akan dilakukan suatu penelitian peningkatan sifat mekanik melalui proses media pendinginan tungku, udara, air, dan oli.

\section{TINJAUAN PUSTAKA}

\section{Baja Karbon Rendah}

Baja karbon rendah merupakan paduan yang memiliki kandungan karbon $\leq 0,30 \% \mathrm{C}$, disamping itu mengandung unsur lain yaitu $\mathrm{Si}, \mathrm{Mn}, \mathrm{Cu}, \mathrm{P}$ dan S. Sifat dari baja karbon sangat ditentukan oleh kandungan karbon yang terdapat dalam paduan baja, sehingga baja karbon secara umum dikelompokkan menjadi tiga jenis yaitu : 1. Baja karbon rendah mengandung unsur karbon $(\leq 0,30 \% \mathrm{C})$.

2. Baja karbon sedang mengandung unsur karbon $(0,30 \% \leq \mathrm{C} \leq 0,45 \%)$.

3. Baja karbon tinggi mengandung unsur karbon $(0,45 \% \leq \mathrm{C} \leq 1,70 \%)$.

Kandungan karbon di dalam paduan baja juga berpengaruh terhadap kekuatan dan keuletan baja. Kalau kadar karbon dari baja karbon bertambah, maka kekuatannya bertambah, sedangkan perpanjangannya, pengecilan luas dan harga benturnya berkurang dan menjadi sukar dilas.

Baja karbon biasanya dilunakkan, dinormalkan dan ditemper sebelum dipakai. Dibandingkan dengan melunakkan, menormalkan baja karbon memberikan butir-butir halus dan memberikan harga yang lebih tinggi untuk batas mulur serta kekuatan tarik. 


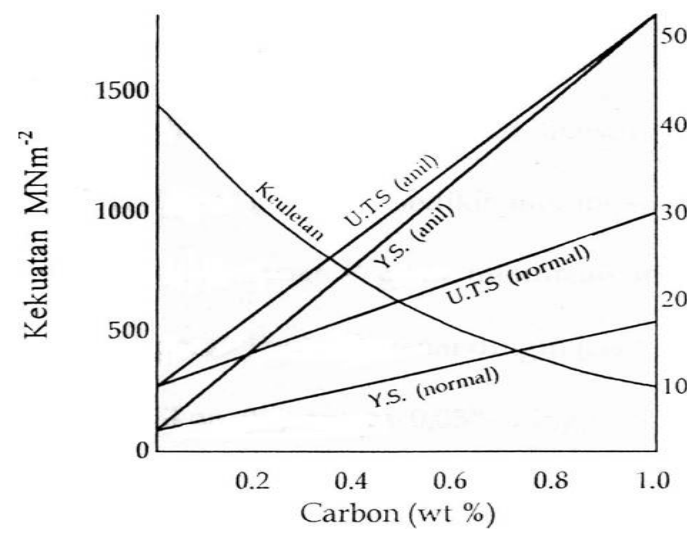

Gambar 1. Pengaruh kandungan karbon dan perlakuan panas pada sifat-sifat mekanis.

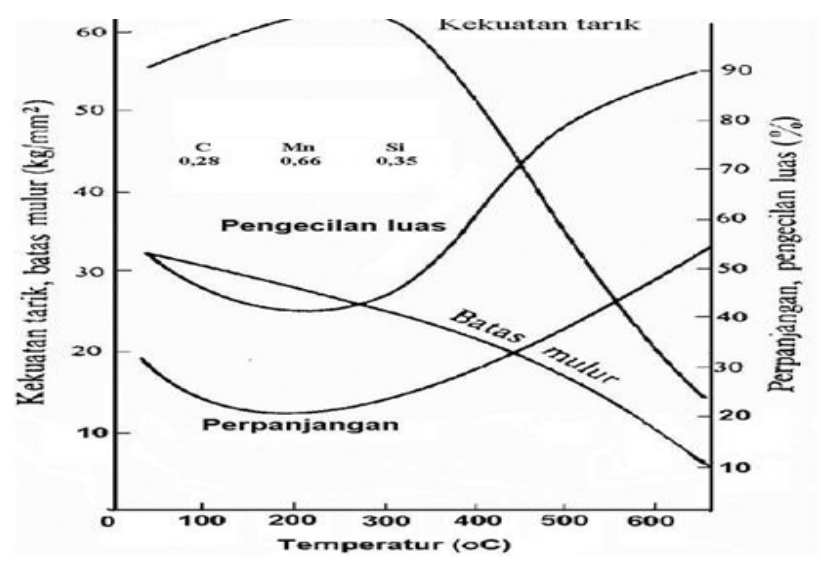

Gambar 2. Pengujian tarik panas dari baja karbon yang dinormalkan pada berbagai temperatur.

Harga bentur baja turun sesuai dengan turunnya temperatur. Temperatur transisi didefinisikan sebagai temperatur dimana harga bentur turun cepat sekali. Ini merupakan indeks yang penting untuk keuletan dari logam yang dipergunakan pada temperatur rendah. Sebagai penggantinya, biasa dipakai temperatur transisi $15 \mathrm{ft}-\mathrm{lb}(\operatorname{Tr} 15)$ sebagai ukuran dari penggunaan yang aman dari logam, yaitu temperatur dimana harga bentur charpy dengan takikan $\mathrm{V}$ adalah 15 $\mathrm{ft}-\mathrm{lb}$.

Temperatur transisi sangat dipengaruhi oleh kadar karbon. Kalau kadar karbon bertambah 0,1 $\%$, maka Tr 15 meningkat 13 oC, untuk kandungan karbon kurang dari 0,3\% dan $28 \mathrm{oC}$ untuk daerah kadar karbon antara 0,3\% sampai 0,57\%. Pada gambar 3, menunjukkan perubahan harga bentur dari baja yang mempunyai kekuatan tarik 42 dan $46 \mathrm{~kg} / \mathrm{mm} 2$, terhadap perubahan temperatur. Untuk mengukur sifat-sifat mekanis dari baja karbon, batang uji diambil dari bagian-bagian yang berhubungan dengan bahan utama, atau bahan utama yang telah dilunakan, dinormalkan dan ditemper sebelum pengujian.

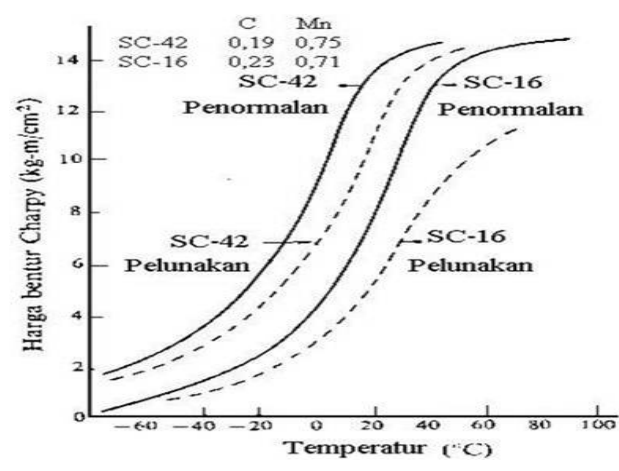

Gambar 3. Harga bentur dari baja karbon.

\section{Klasifikasi Baja}

Baja merupakan salah satu bahan konstruksi yang paling penting. Sifat-sifatnya yang paling penting dalam penggunaan konstruksi adalah kekuatan, ketangguhan dan keuletan yang baik dibandingkan terhadap bahan-bahan lain yang tersedia. Pertimbangan-pertimbangan lainnya dalam penggunaan baja termasuk kemudahan penyediaannya secara luas dan daya tahannya (durability).

Sifat dan produk baja tersebut banyak dipengaruhi oleh sifat kimia dan proses pembuatannya. Untuk keperluan industri pengelompokan baja menjadi beberapa kelompok berdasarkan beberapa karakteristik umum.

\section{Baja Berdasarkan Bentuk Produk}

Hal ini sangat umum digunakan dalam industri baja, misalnya baja batangan, baja profil, gulungan strip baja dan sebagainya.

Baja khusus terdiri dari baja paduan rendah dan baja paduan tinggi yang dibuat dengan menambahkan macam-macam unsur paduan kedalam baja karbon. Mangan dan juga silisium biasanya tidak dapat dihindarkan selalu tercampur pada waktu pengolahan baja, sehingga dalam hal ini baja tersebut tidak masuk dalam kategori baja khusus, kecuali kalau unsur-unsur tersebut ditambahkan sebagai unsur paduan.

Baja disebut baja paduan rendah jika unsur paduannya ditambahkan $1 \%$ sampai $2 \%$, dan disebut baja paduan menengah jika unsur paduannya ditambahkan $2 \%$ sampai $5 \%$, dan disebut baja paduan tinggi jika unsur paduannya di atas $5 \%$, namun dalam hal ini tidak dibedakan secara tepat. 
Baja khusus biasanya baru dipergunakan setelah melalui pencelupan dingin, penormalan, dan penemperan untuk memperbaiki sifat-sifatnya. Baja karbon dikeraskan dan dikuatkan dengan pencelupan dingin tetapi mampu kerasnya kurang baik karena hanya kulitnya atau bagian luarnya saja yang mengeras. Lapisan yang mengeras menjadi lebih tebal dengan menambah $\mathrm{Mn}, \mathrm{Cr}$, Mo dan Ni. Baja dengan penambahan unsur tersebut dapat dikatakan mempunyai mampu keras yang tinggi. Hal ini dikarenakan karbon larut dalam asutenit yang menyebabkan baja menjadi keras dengan pencelupan dingin.

Pada gambar 4 , menunjukkan hubungan antara kekerasan yang tertinggi dari berbagai baja yang dicelupkan dingin terhadap kadar karbonnya. Titik-titik hitam menunjukkan harga-harga untuk baja karbon. Dengan semakin tinggi kadar karbon yang terkandung maka kekerasan juga semakin meningkat. Namun untuk kandungan karbon antara $0,5 \%-0,6 \%$ kekerasan tidak lagi meningkat atau dengan kata lain konstan pada kekerasan maksimal.

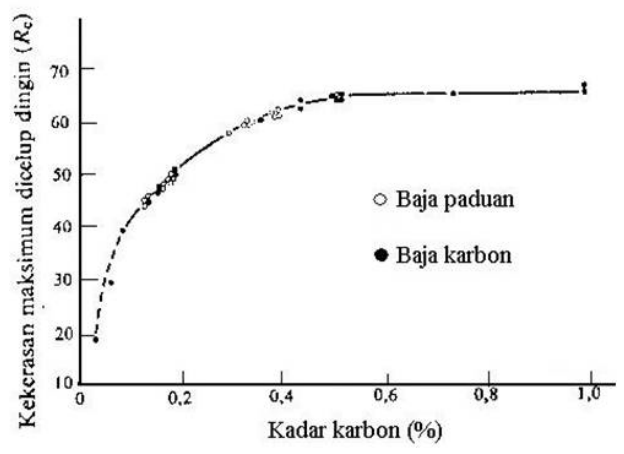

Gambar 4. Kadar karbon dan kekerasan maksimum baja setelah di celup dingin (Quenching)

Dalam penormalan, meskipun baja mempunyai mampu keras tinggi tetapi ada perbedaan kekerasan yang kecil antara kulit dan bagian tengahnya. Ada hubungan antara dua sifat mekanis dari baja karbon rendah yang tidak tergantung pada komposisi kimia seperti yang terlihat pada gambar 5 sampai gambar 10, dimana gambar tersebut menunjukan hubungan sifat-sifat dari macam-macam baja karbon paduan rendah yang mengalami perlakuan panas baik dengan penormalan, penemperan atau dengan pencelupan dingin dan penemperan.

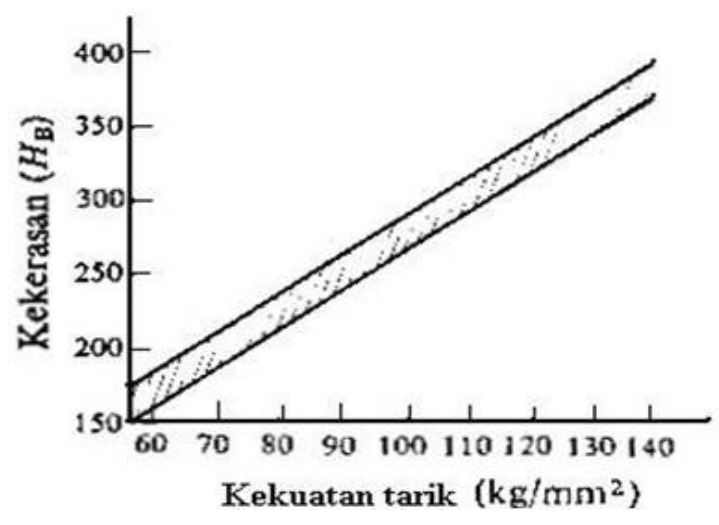

Gambar 5. Kekuatan tarik dan kekerasan brinell baja karbon paduan rendah

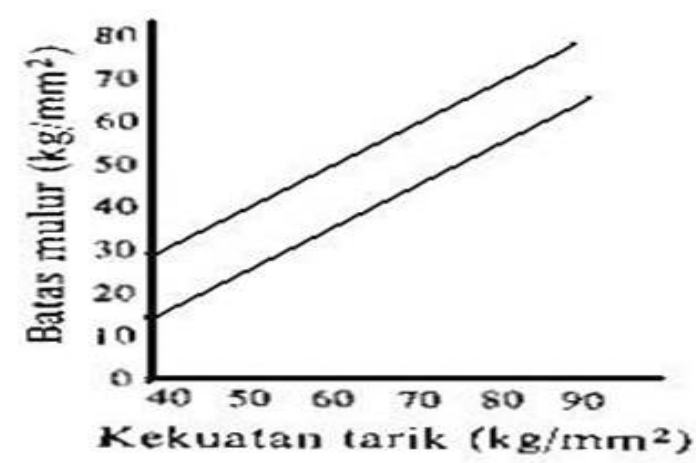

Gambar 6. Hubungan antara kekuatan tarik dan batas mulur baja karbon paduan rendah yang dinormalkan dan di temper.

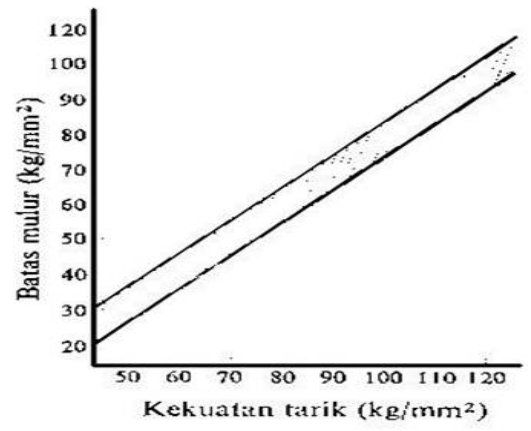

Gambar 7. Kekuatan tarik dan batas mulur dari baja karbon paduan rendah yang dicelup dingin dan ditemper.

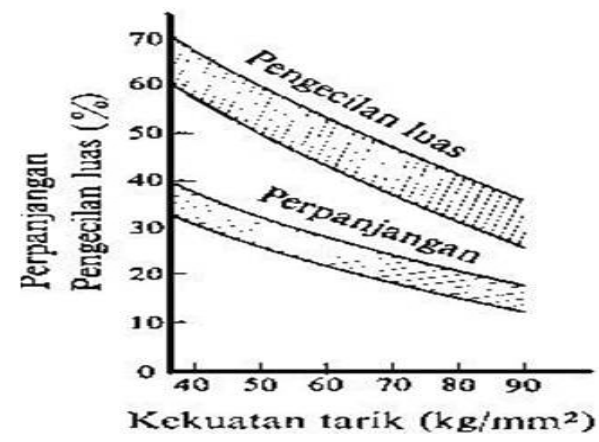

Gambar 8. Ketergantungan perpanjangan dan pengecilan pada kekuatan tarik dari baja karbon paduan rendah setelah dinormalkan dan ditemper. 


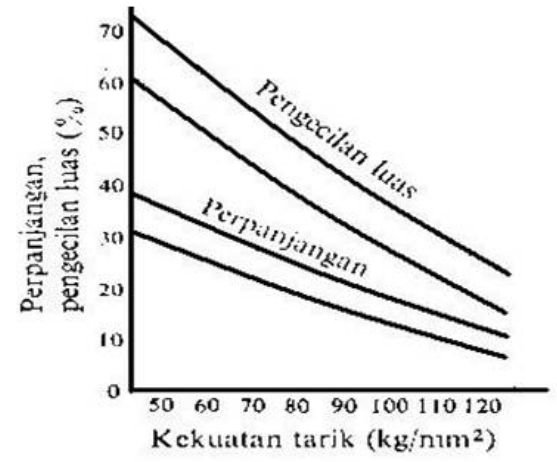

Gambar 9. Hubungan antara kekuatan tarik, dan pengecilan luasdari baja karbon paduan rendah setelah dicelup dingin dan ditemper.

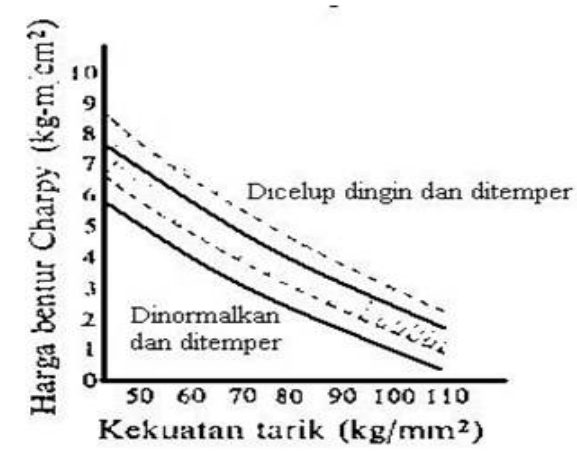

Gambar 10. Hubungan antara kekuatan tarik dan harga bentur.

Pengaruh Unsur Paduan Terhadap Sifat Baja Baja karbon yang banyak terdapat dipasaran umumnya mengandung sulfur $\leq 0,005 \%$. Sulfur (S) dapat menyebabkan baja menjadi rapuh atau hot shortness karena unsur sulfur bersenyawa dengan besi $(\mathrm{Fe})$ membentuk $\mathrm{FeS}$ (paduan autectic) yang dapat menyebabkan temperatur leburnya rendah.

Kandungan mangan (Mn) didalam baja karbon antara $0,03 \%$ sampai $1 \%$, adapun fungsi dari mangan adalah untuk menghindarkan terjadinya hot shortness dengan mengikat unsur sulfur (S) menjadi MnS. Kemudian MnS akan terpisah dari paduan baja yang berupa terak. Pospor $(\mathrm{P})$ yang terkandung di dalam paduan baja karbon $\leq 0,04 \%$, pospor cenderung larut didalam ferit, dan akan menurunkan keliatan sehingga baja akan cenderung pecah ketika dilakukan pengerolan dingin (cold-short).

\section{Diagram Kesetimbangan Fe - Fe3C}

Panduan dasar untuk perlakuan panas besi dan baja, digunakan diagram kesetimbangan $\mathrm{Fe}-$ Fe3C, seperti terlihat pada gambar 11. Dari gambar tersebut dapat terlihat fasa-fasa pada kondisi tertentu. Fasa-fasa tersebut antara lain ferit (_), cementit (Fe3C), austenit (g), besi (d) atau campuran dari fasa-fasa tersebut yang keberadaannya tergantung pada kondisi temperatur dan kandungan karbon.

Dari diagram kesetimbangan $\mathrm{Fe}-\mathrm{Fe} 3 \mathrm{C}$ juga dapat diketahui proporsi dari tiap-tiap fasa yang timbul dalam kesetimbangan dua fasa. Karena percobaan ini menyangkut baja karbon rendah, maka pembahasan difokuskan pada daerah baja hypoectectoid, yaitu daerah dimana kadar karbonnya dibawah $\leq 0,08 \%$.

Larutan padat _ atau ferit merupakan larutan padat intertisi dengan kelarutan karbon dalam _ yang rendah sekali $(+0,008 \% \mathrm{C})$ pada temperatur ruang, dan $+0,025 \% \mathrm{C}$ pada temperatur $723^{\circ} \mathrm{C}$. Fasa ini lunak dan mempunyai kekuatan yang rendah, untuk lebih jelasnya dapat diamati pada gambar 11.

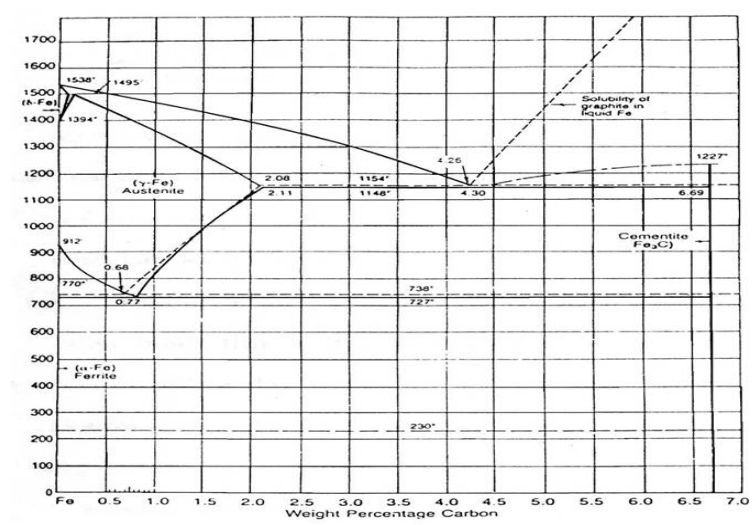

Gambar 11. Diagram kesetimbangan $\mathrm{Fe}-\mathrm{Fe} 3 \mathrm{C}$.

Perlit merupakan fasa eutectoid dengan + $0,8 \% \mathrm{C}$ dan terbentuk pada temperatur $723^{\circ} \mathrm{C}$ garis A1 pada gambar 13. Strukturnya mirip lamellar campuran ferit dan cementit yang memiliki kekuatan dan kekerasan yang lebih baik dari ferit. Atau untuk lebih jelas kondisi _ maupun kondisi dari g dapat diamati pada gambar 13 .

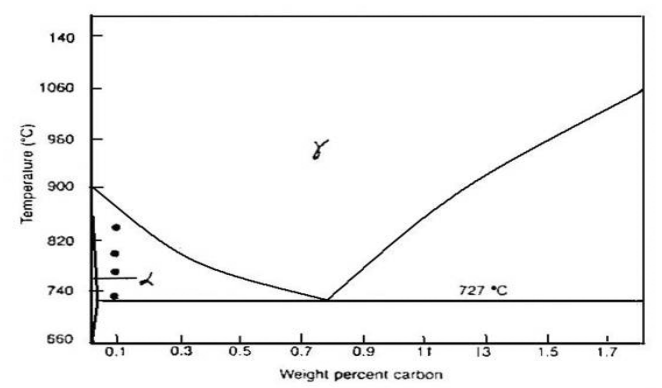

Gambar 12. Diagram Fe - C dengan empat indikasi temperatur interkritikal annealing. 
Austenit (larutan padat g) merupakan larutan padat intertisi dari karbon dalam besi g. Kelarutan maksimal kandungan karbon sebesar $+2,06 \%$ pada temperatur $1148 \mathrm{oC}$, sifat ketangguhan tinggi, tidak stabil pada temperatur ruang

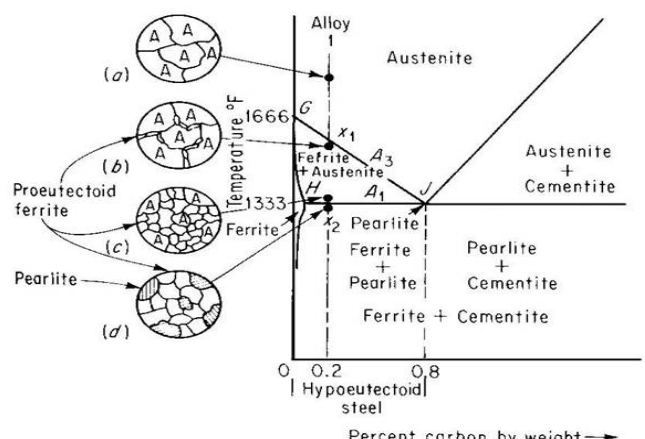

Gambar 13. Skematis fasa-fasa yang hadir pada temperatur tertentu.

Pada daerah hypoectectoid ini terdapat dua garis yang mempunyai arti penting. Pertama adalah Garis A1 (gambar 13) atau garis temperatur kritis bawah (low ritical-temperature line). Kedua adalah garis A3 atau garis temperatur kritis (uppercritical-temperature line).

Dari gambar 13, garis A1 terdapat kesetimbangan antara austenit dan perlit (ferit + sementit). Bila temperatur dinaikkan maka kesetimbangan akan bergeser kekiri (daerah austenit), dan bila temperatur diturunkan maka akan bergeser kearah daerah perlit. Dapat diilustrasikan seperti skema di bawah ini :

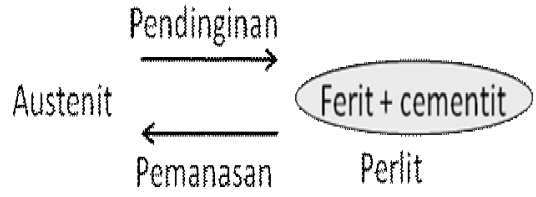

Dari garis A3 terdapat kesetimbangan antara austenit dan untuk menghitung proporsi ferit dan austenit di dalam dua fasa (intercritical region) pada daerah tertentu digunakan hukum level rule, tentang jumlah relative dan kandungan karbon dari masing-masing fasa.

Dari gambar 12. juga bisa ditentukan kadar karbon dan proporsi masing-masing fasa (ferit dan austenit). Misalnya baja karbon $0,4 \%$ pada temperatur $\mathrm{A} 1$ (misalkan $\mathrm{X}$ oC). Untuk menentukan kadar karbon, tarik garis horizontal pada temperatur $\mathrm{X}$ oC tersebut hingga memotong garis $\mathrm{A} 3$ dan garis solidus _ dan diperoleh dua buah titik a dan b. kemudian tariklah garis vertical kebawah melalui titik a dan b sampai memotong absis (\% C) di titik a1 dan b1, jadi kadar karbon ferit dan austenit adalah a \% dan b\%.

Sedangkan untuk proporsi ferit dan austenit dihitung dengan aturan pengungkit, dimana titik tumpu dari sistem pengungkit adalah titik C. Untuk menghitung persentase ferit dan austenit dapat digunakan persamaan sebagai berikut:

$$
\begin{gathered}
\% \text { Ferit }=\frac{\left(b_{1}-0.4\right)}{\left(b_{1}-a_{1}\right)} \times 100 \% \\
\% \text { Austenit }=\frac{\left(b_{1}-0.4\right)}{\left(b_{1}-a_{1}\right)} \times 100 \%
\end{gathered}
$$

Transformasi yang terjadi pada garis A1 dan A2 dikendalikan oleh laju difusi, sehingga temperatur kritis dipengaruhi oleh komposisi kimia.

Laju pemanasan yang cepat dapat menyebabkan waktu difusi yang singkat dan dapat meningkatkan temperatur kritis. Sebaliknya dengan pendinginan yang cepat dapat menurunkan temperatur kritis.

\section{Proses Perlakuan Panas (Heat Treatment) Prinsip Dasar Perlakuan Panas (Heat Treatment)}

Perlakuan panas (Heat Treatment) adalah suatu proses untuk merubah struktur dan sifat logam dengan jalan memanaskan logam sampai suhu tertentu, kemudian didinginkan dengan media pendingin udara maupun media pendingin air, sehingga menghasilkan sifat-sifat tertentu yang diinginkan antara lain: sifat keras atau sifat ketahanan logam terhadap penekanan.

Pada baja, semua proses dasar pengerjaan panas berhubungan dengan transformasi atau penguraian austenit. Maka sifat dan kenyataan yang diperoleh pada hasil transformasi memperluas aneka ragam kegunaan, sifat fisik dan sifat mekanik logam.

\section{Tujuan Heat Treatment}

Proses pengerjaan yang dilakukan bertujuan untuk merubah sifat dan struktur logam menjadi sifat yang diinginkan, seperti:

1. Mengeraskan logam.

2. Melunakan logam.

3. Menghilangkan internalstress, yaitu tegangan dalam yang diakibatkan oleh pengerjaan dingin, pengelasan, penempaan dan pembentukan.

4. Menyempurnakan keliatan dan keuletan.

5. Meningkatkan sifat tahan panas dan tahan gesekan. 
Khusus untuk baja, proses ini dapat menyempurnakan sifat-sifat listrik dan magnet pada baja.

\section{Faktor-faktor Yang Mempengaruhi Heat Treatment}

Didalam proses heat treatment ada beberapa faktor yang menentukan berhasil atau tidaknya hasil yang diharapkan dalam pelaksanaan proses tersebut antara lain:

1. Kecepatan pemanasan.

2. Kecepatan pendinginan.

3. Waktu penahanan (holding time).

4. Media pendinginan yang digunakan.

Faktor-faktor tersebut diatas telah diterapkan dalam spesifikasi sehingga untuk material yang berbeda jenis maupun karakteristik yang diharapkan terdapat perbedaan melalui masing-masing tahap tersebut.

\section{Jenis-jenis Proses Heat Treatmen}

Ada beberapa proses heat treatment yang dapat dilakukan, Masing-masing bertujuan untuk mendapatkan sifat-sifat mekanis logam yang diharapkan. Jenis-jenis proses heat treatment adalah sebagai berikut:

\section{Proses Anil (Annealing)}

Merupakan proses pemanasan sampai diatas suhu transformasi $\left(723^{\circ} \mathrm{C}\right)$, kemudian didinginkan secara bertahap. Proses ini menghasilkan ferit dan perlit yang lunak sehingga logam menjadi lunak. Annealing dilakukan pada bahan-bahan yang telah mengalami cold working dan hot working, pada baja karbon rendah atau kabel-kabel baja untuk menghilangkan tegangan dalam dan perlunakan bahan.

Lamanya pemanasan dalam proses annealing atau holding time sangat berpengaruh terhadap hasil akhir dari proses tersebut semakin lama waktu tahan yang dilakukan maka perubahan-perubahan yang terjadi pada struktur-struktur logam akan lebih merata diseluruh bagian.

Pengaruh dari Anneling terhadap kekuatan tarik, kekerasan, kelenturan, dan pertumbuhan Kristal dapat dilihat pada Gambar 14. di berikut ini.

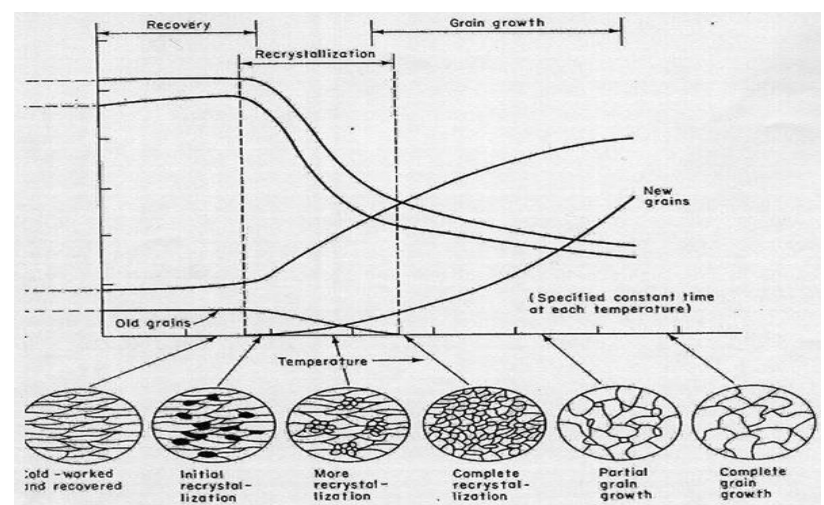

Gambar 14. Pengaruh anneling terhadap kekuatan tarik, kekerasan, kelenturan, dan pertumbuhan kristal.

\section{Normalizing (Normalisasi)}

Adalah peristiwa pemanasan logam baja sehingga seluruh fasa menjadi austenit $(y)$ dan kemudian didinginkan diudara sehingga mencapai suhu kamar sehingga menghasilkan struktur normal ferit dan perlit.

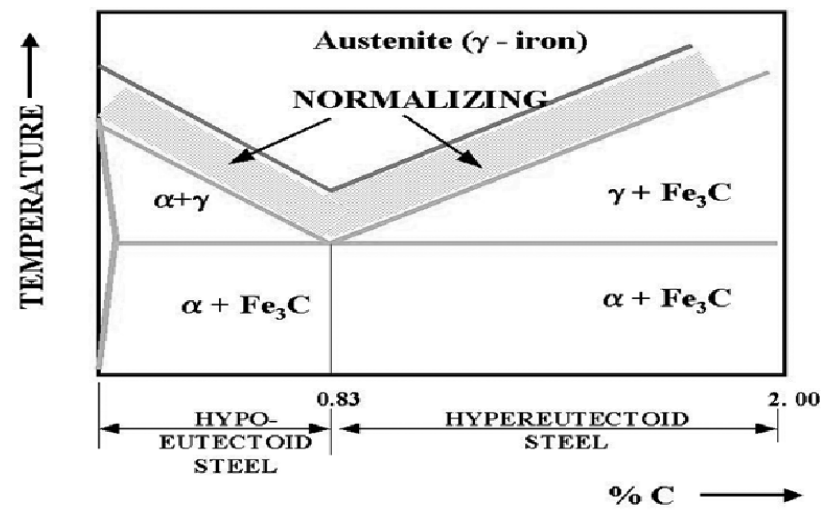

Gambar 15. Temperatur normalizing untuk besi hypoeutectoid dan hypereutectoid.

\section{Proses Pengerasan (Hardening)}

Proses pengerasan adalah proses pemanasan baja diatas temperatur austenisasi untuk memperoleh sifat yang sangat keras dari suatu material, dan ditahan pada waktu penahanan tertentu serta didinginkan dengan cepat pada suatu media pendingin. Kekerasan yang dapat dicapai tergantung laju pendinginan, kadar karbon dan ukuran benda. Pada baja paduan, jenis dan jumlah paduan akan dipengaruhi kemampuan pengerasan.

\section{Tempering}

Adalah proses perlakuan panas kembali pada temperatur dibawah temperatur tertentu setelah mengalami proses hardening. Tempering bertujuan untuk meningkatkan ketangguhan serta menurunkan kekerasan serta mempertinggi keuletan: 
1. Tempering suhu rendah $\left(100^{\circ} \mathrm{C}-200{ }^{\circ} \mathrm{C}\right)$ Tujuannya untuk mengurangi tegangantegangan dalam bahan akibat pendinginanpendinginan cepat. Proses ini digunakan untuk alat-alat kerja yang tidak mengalami beban berat, seperti: alat-alat potong, mata bor yang dipakai untuk kaca dan Iain-lain.

2. Tempering suhu menengah $\left(200^{\circ} \mathrm{C}-450^{\circ} \mathrm{C}\right)$ Untuk meningkatkan keuletan dan menurunkan sedikit kekerasannya. Biasa digunakan pada alat-alat kerja yang menerima beban berat, seperti: palu, pahat, pegas dan Iain-lain.

3. Tempering suhu tinggi $\left(450^{\circ} \mathrm{C}-650^{\circ} \mathrm{C}\right)$

CONVENTIONAL QUENC̈HING AND TEMPERING

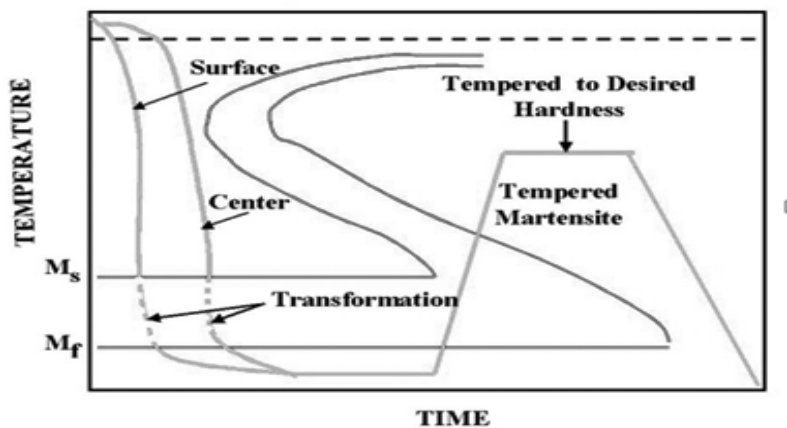

Gambar 16. Process conventional quenching and tempering.

Diagram Transformasi Isothermal (IT-diagram) Untuk melihat kondisi transformasi fasa yang terjadi pada kecepatan tertentu dari suatu proses perlakuan pada baja karbon dapat digunakan diagram Isothermal-Transformasi pada gambar 17. dan gambar 18. Diagram IsothermalTransformasi biasa juga dikenal dengan nama ITT atau diagram TTT (transformasi, temperatur dan waktu).

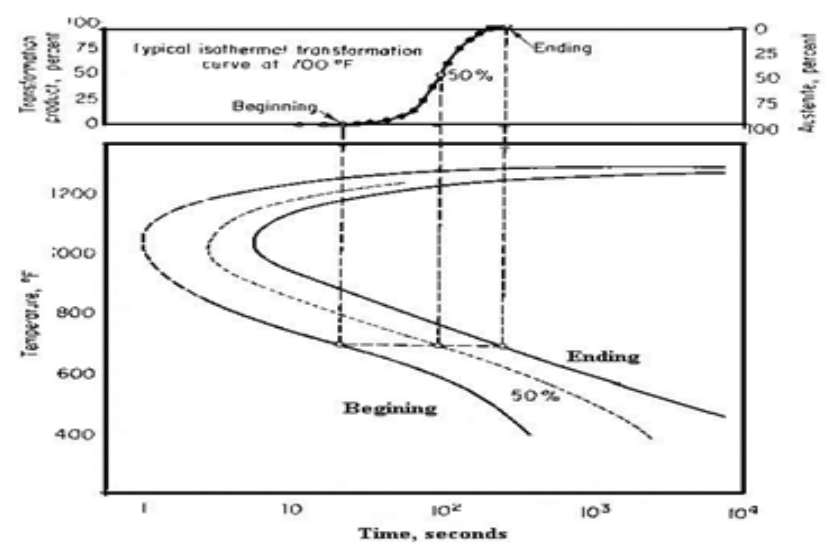

Gambar 17. Diagram isotermal-transformasi.

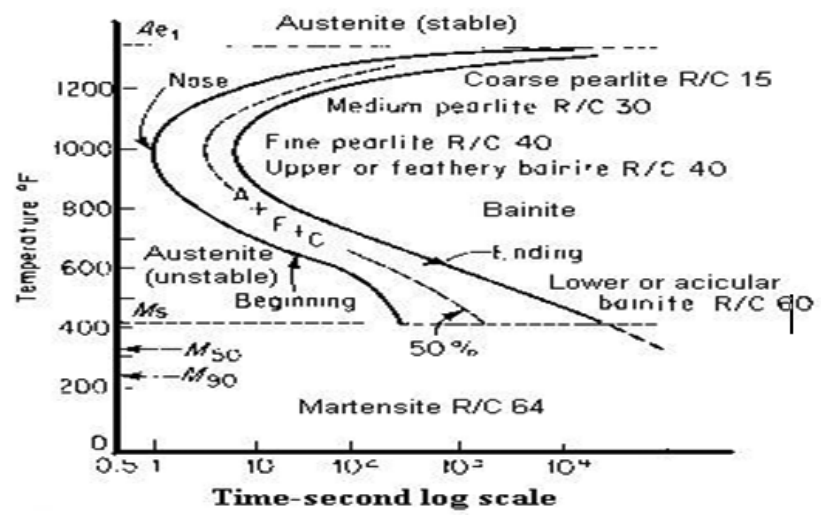

Gambar 18. Diagram isothermal - transformasi (eutectoid) baja.

\section{Diagram Tranformasi Pendinginan Kontinyu (CT - Diagram)}

Secara teoritis kurva laju pendinginan pada diagram I-T tidak dapat digunakan untuk menentukan pada pendinginan kontinu. Pada diagram IT diperlihatkan hubungan antara waktu - temperatur untuk transformasi austenit dan hal ini akan terjadi hanya pada temperatur konstan, tetapi perlakuan panas meliputi transformasi pada pendinginan kontinu.

Untuk menentukan pendinginan kontinu digunakan $\mathrm{C}$-T diagram (cooling-transformation diagram) dapat diamati pada gambar 19.

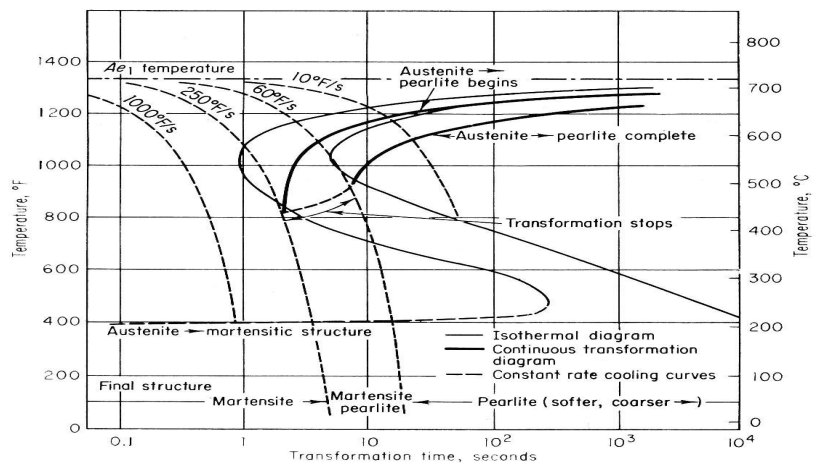

Gambar 19. Diagram transformasi pendinginan kontinue (CCT)

\section{Media Pendinginan}

Media pendinginan yang digunakan biasanya berupa air, minyak, udara, air garam, larutan $\mathrm{NaOH}$, dan larutan polimer. Setiap jenis media pendingin memiliki kecepatan pendinginan yang berbeda. Dari media yang digunakan yang memiliki waktu pendinginan paling lama adalah udara dan memiliki waktu pendinginan paling cepat adalah air garam. Sebagai gambaran beberapa pendingin dan kecepatan pendinginan dapat diamati pada gambar 20. 
Dari gambar 20 terlihat bahwa air merupakan pendinginan tercepat kedua dibandingkan dengan media yang lain. Namun air paling banyak digunakan untuk pengerasan logam, karena air mudah didapat, paling murah dan tanpa menyebabkan polusi. Dalam pendinginan dengan menggunakan media angin, perlu juga diperhatikan jangan sampai kekurangan air, karena dapat meyebabkan material yang di celup menjadi retak.

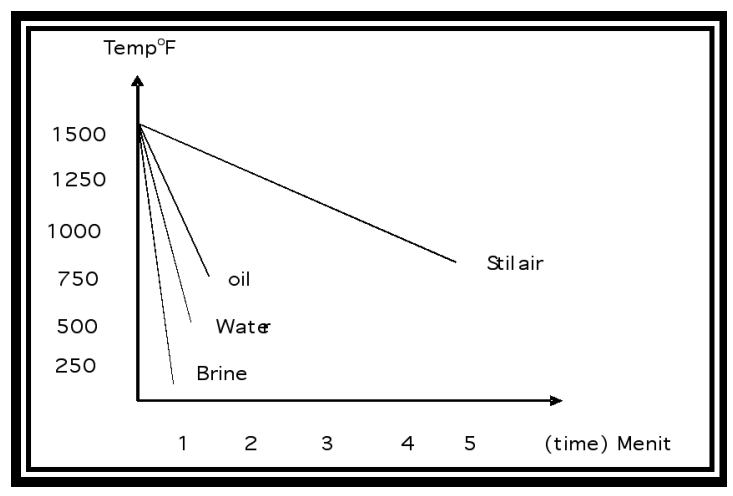

Gambar 20. Kecepatan pendinginan dari beberapa pendingin.

Jika digunakan media air garam dengan penambahan hanya sekitar $5 \%$ sampai $10 \%$ dapat meningkatkan daya tahan pendinginnya bahkan semakin besar. Selain dari itu larutan garam juga berfungsi untuk memecahkan kantong uap yang terjadi sekeliling logam. Untuk konsentrasi yang optimal larutan garam $(\mathrm{NaCl})$ sebesar $10 \%$ karena pada kondisi ini logam yang didinginkan memiliki kekerasan yang paling tinggi.

\section{Struktur Mikro}

\section{Ferit}

Baja yang mengandung struktur mikro ferit terdapat pada baja yang memiliki kandungan karbon rendah. Dimana kelarutan karbon di dalam fasa $a$ sekitar $0,008 \%$. Struktur mikro dari butir ferit tersebut berbentuk polygonal. Ferit merupakan fasa yang bersifat lunak dengan kekuatan rendah.

\section{Austenit}

Jika material baja dipanaskan sedikit diatas temperatur transformasi dengan waktu yang cukup, maka diperoleh larutan padat austenit dengan struktur kps. Fasa ini dapat melarutkan karbon berbentuk larutan padat intertisial sebanyak 2,06 $\%$ pada temperatur $1148 \mathrm{oC}$ dan kemudian turun menjadi $0,8 \%$ pada temperatur 723 oC. Reaksi setimbang yang terjadi waktu pendinginan adalah sebagai berikut:

$$
\begin{aligned}
\text { Austenit } & \rightarrow \text { Ferit }+ \text { Cementit } \\
\Gamma & \rightarrow \alpha+\mathrm{Fe}_{3} \mathrm{C}
\end{aligned}
$$

Pada diagram kesetimbangan $\mathrm{Fe}-\mathrm{Fe} 3 \mathrm{C}$, terlihat bahwa transformasi yang dapat terjadi pada proses pemanasan adalah transformasi perlit menjadi austenit pada temperatur di atas garis A3.

\section{Martensit}

Transformasi martensit hanya terjadi pada austenit yang dilakukan pendinginan dengan sangat cepat tanpa disertai penyusunan atom karbon secara difusi pada kisi-kisi austenit. Pembentukan martensit terjadi oleh proses pergeseran atom sebesar jarak atom-atomnya. Disamping itu selama proses pembentukan martensit tidak terjadi perubahan komposisi di dalam larutan padat.

Akibat pergeseran atom ini, menyebabkan terjadinya perubahan struktur dari kubik pemusatan sisi (kps) menjadi tetragonal pemusatan ruang (tpr). Pembentukan martensit dimulai pada garis martensit stars (Ms) dan berakhir pada garis martensit finish (Mf). Garis Ms dan Mf tidak dipengaruhi oleh laju pendinginan tetapi ditentukan oleh komposisi kimia.

Martensit stars (Ms) sebagai fungsi komposisi kimia menurut K-E Thelning memformulasikan sebagai berikut:

\section{Ms $(0 \mathrm{C})=$ 561-474 C-33 Mn- 17 Ni-17 Cr - 21 Mo.}

Dari rumus empiris yang diturunkan $K-E$ Thelning, maka unsur yang paling dominant menentukan martensit adalah karbon. Hal ini dapat dilihat pada gambar 20 bahwa dengan semakin besar kadar karbon dalam baja maka temperatur martensit starts (Ms) dan temperatur martensit finish (Mf) akan menurun.

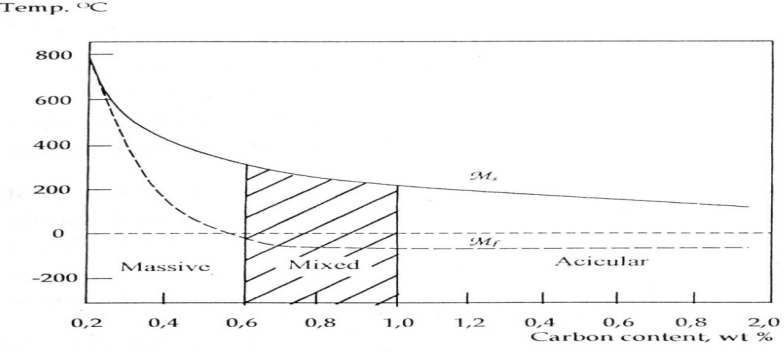

Gambar 21. Pengaruh kadar karbon terhadap temperatur Ms dan Mf. 
Dari gambar tersebut dapat pula terlihat bahwa sebagian besar baja dengan kandungan karbon lebih dari 0,5\% mempunyai temperatur Ms dibawah temperatur ruang. Hal ini berarti setelah proses pengerasan selesai dilakukan maka baja tersebut masih mengandung sejumlah austenit yang disebut austenit sisa.

Hal-hal yang penting dari karakteristik transformasi martensit adalah:

1. Transformasi martensit terjadi tanpa proses difusi. Hal ini karena transformasi martensit berlangsung dengan kecepatan tinggi.

2. Transformasi martensit terjadi tanpa adanya perubahan komposisi kimia pada fasa awalnya. Posisi dari atom-atom karbon terhadap atomatom besi didalam struktur martensit adalah sama keadaanya didalam austenit.

3. Jenis martensit yang dihasilkan sangat tergantung pada jumlah kandungan karbon di dalam baja. Bila kandungan karbonnya rendah maka jenis martensit yang terbentuk adalah Lath martensit. Bila kadar karbonnya sedang akan terbentuk plate martensit.

4. Stuktur kristal yang dihasilkan oleh transformasi martensit adalah body center tetragonal (BCT).

\section{Bentuk Martensit}

Berdasarkan penelitian yang dilakukan Maider dan Krauss pada baja karbon paduan, ditemukan dua macam bentuk martensit, yaitu Lath dan Plate. Bentuk dari martensit ini dipengaruhi oleh kadar karbon. Untuk kadar karbon kurang dari 0,6 \% C yang terbentuk adalah lath martensit, sedang kadar karbon lebih dari 0,1\% $\mathrm{C}$ yang terbentuk adalah plate martensit. Untuk kadar karbon antara $0,6 \%-1,0 \%$ yang terbentuk adalah campuran antara keduanya. Hubungan bentuk martensit dengan jumlah karbon diperlihatkan dalam gambar 22 .

\section{Sifat Mekanis Martensit}

Struktur martensit didalam baja merupakan stuktur yang mempunyai kekerasan yang paling tinggi. Kekerasan dari martensit ini dipengaruhi oleh besarnya kandungan karbon dalam baja. Seperti terlihat pada gambar 23, kekerasan martensit sangat sensitif.

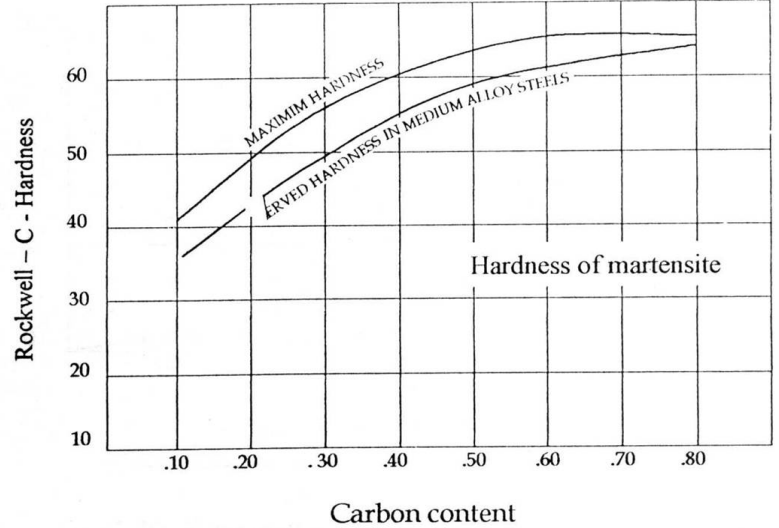

Gambar 22. Kekerasan martensit sebagai fungsi kandungan karbon.

\section{Sifat Mekanis Martensit}

Struktur martensit didalam baja merupakan stuktur yang mempunyai kekerasan yang paling tinggi. Kekerasan dari martensit ini dipengaruhi oleh besarnya kandungan karbon dalam baja. Seperti terlihat pada gambar 23, kekerasan martensit sangat sensitif.

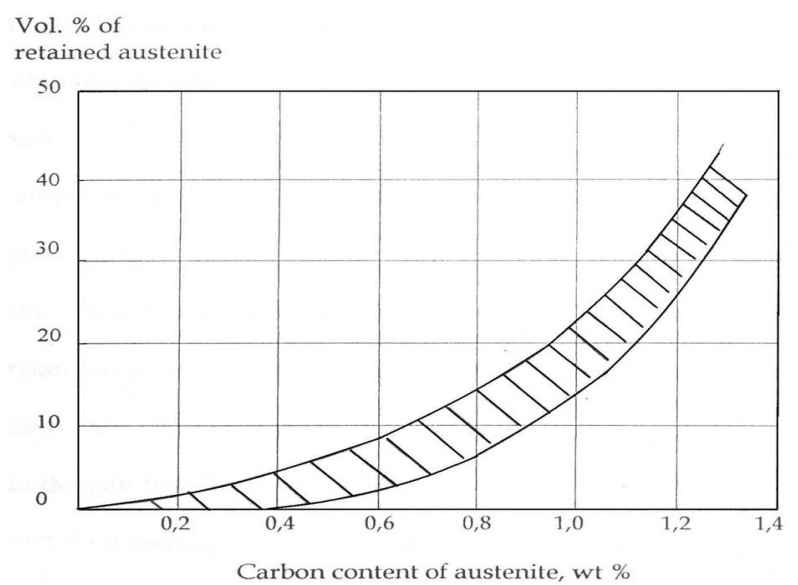

Gambar 23. Pengaruh kadar karbon terhadap sisa austenit sisa.

Terhadap kandungan karbon dibawah 0,2 $\%$. Kenaikan kekerasan martensit sampai dengan kandungan karbon 0,4 \% masih cukup tinggi, namun diatas $0,4 \%$ kenaikannya tidak seberapa tinggi. Hal ini karena dengan meningkatnya kadar karbon maka austenit sisa yang terbentuk juga semakin meningkat. Sehingga peningkatan kekerasannya menjadi relative lebih kecil.

\section{METODOLOGI PENELITIAN}

Diagram Alir Penelitian 


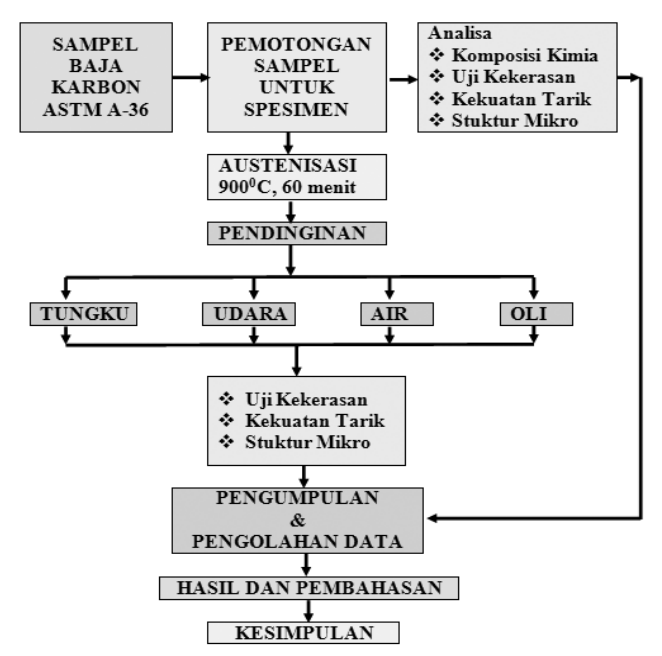

Gambar 24. Giagram Alir Penelitian

\section{Bahan dan Alat}

\section{Bahan Yang Digunakan}

Material baja karbon rendah ASTM A-36 Alat Yang Digunakan

1. Gergaji besi, berfungsi untuk memotong benda uji.

2. Muffle Furnace, berfungsi untuk memanaskan benda uji.

3. AAS (Atomic Absorption Spectrophotometer), berfungsi untuk menganalisa komposisi kimia benda uji.

4. Alat uji kekerasan, berfungsi untuk menguji kekerasan benda uji.

5. Mesin poles, berfungsi untuk menghaluskan benda uji yang telah di mounting sebelum pengujian struktur mikro.

6. Mikroskop Optik Metalografi, berfungsi untuk melihat struktur mikro benda uji.

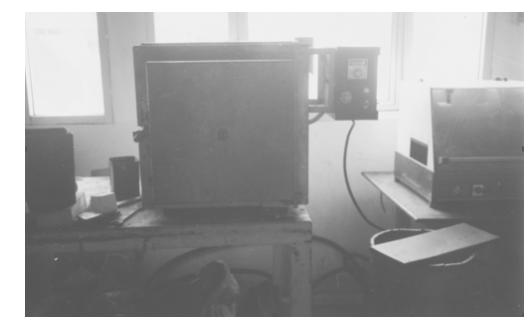

Gambar 25. Muffle furnace

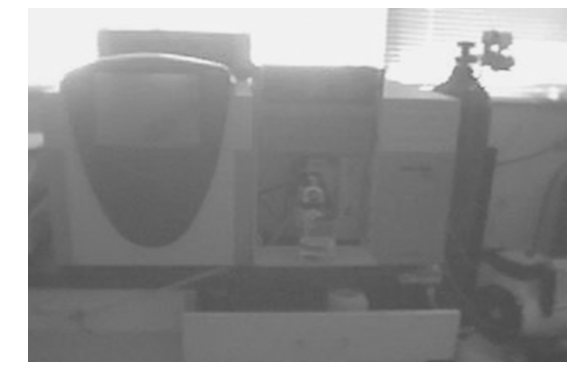

Gambar 26. AAS (Alat analisa komposisi kimia)

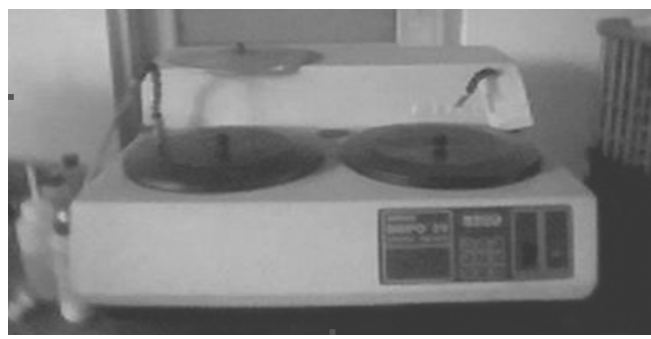

Gambar 27. Mesin poles

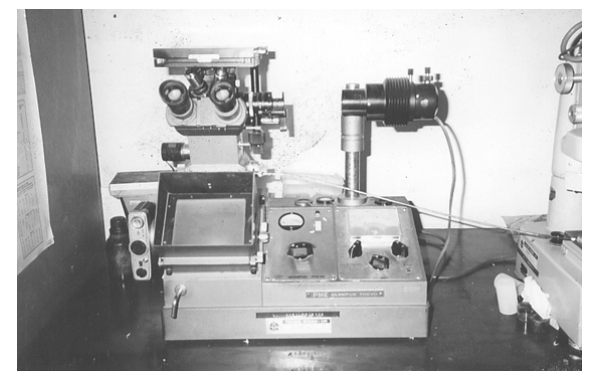

Gambar 28. Mikroskop optic metalografi

\section{Proses Penelitian}

Pengambilan Sampel Uji Tarik dan Regangan

Plat baja spesifikasi ASTM A36, tebal $2 \mathrm{~cm}$ dipo-tong, untuk pembuatan spesimen uji tarik. Bentuk spesimen adalah irisan plat, kemudian spesimen dibubut, dimensi dan ukuran berdasarkan standar JIS.

\section{Pengerjaan Laku Panas Austenisasi}

Pengerjaan austenisasi, spesimen dipanasi di dalam tungku pada suhu $900^{\circ} \mathrm{C}$ selama 1 jam. Penentuan waktu penahanan suhu ini karena dimensi spesimen relatif kecil (diameter $2 \mathrm{~cm}$ ), sedemikian hingga dalam waktu tersebut seluruh dimensi menerima panas merata. Agar supaya permukaan spesimen tidak teroksidasi selama dipanasi, semua spesimen dengan arang cangkang kelapa diletakkan di dalam wadah.

\section{Proses Pendinginan}

Sesudah semua spesimen dipanasi pada suhu $900^{\circ} \mathrm{C}$ dilakukan pendinginan ke dalam suatu media yang memberikan kecepatan pendinginan yang berbeda. Media pendingin yang dipilih adalah:

a. Pendinginan di dalam tungku. Pendinginan media ini, memberikan kecepatan pendinginan paling lambat. Dari hasil pengukuran kecepatan pendinginan sekitar $5^{\circ} \mathrm{C} /$ menit.

b. Pendinginan di udara (ruang terbuka). Pendinginan media ini, memberikan kecepatan pendinginan lambat. Dari hasil pengukuran 
kecepatan pendinginan sekitar $50^{\circ} \mathrm{C} /$ menit.

c. Pendinginan celup oli. Pendinginan media ini, memberikan kecepatan pendinginan lebih cepat. Dari data kecepatan pendinginan sekitar $100 \mathrm{oC} /$ menit.

d. Pendinginan celup air. Pendinginan media ini, memberikan kecepatan pendinginan lebih paling cepat. Dari data kecepatan pendinginan sekitar $150^{\circ} \mathrm{C} /$ menit.

Untuk memberikan gambaran laku panasaustenisasi dapat dilihat pada skematis Gambar 29.

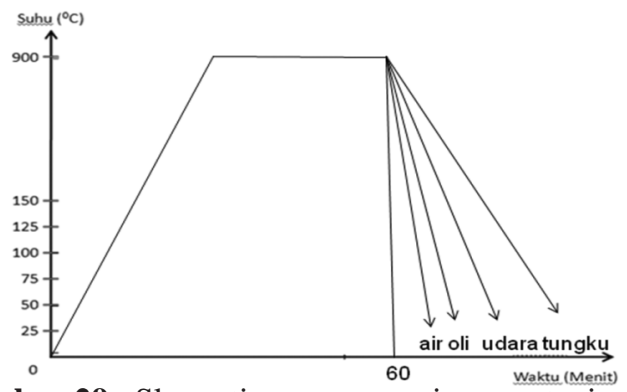

Gambar 29. Skematis cara pengerjaan austenisasi.

Pemanasan pada suhu $900^{\circ} \mathrm{C}$ selama 1 jam. Setiap spesimen didinginkan dengan media pendingin yang memberikan kecepatan pendinginan yang berbeda (tungku, udara, celup oli, dan celup air).

\section{Pengujian}

Terhadap spesimen setalah laku panas austenisasi dilakukan pengujian, sebagai berikut:

1. Uji tegangan tarik dan regangan. Pengujian ini digunakan untuk melihat pengaruh peningkatan kekuatan dan elongasi setelah laku panas austenisasi

2. Uji kekerasan brinnel digunakan untuk mengukur perbedaan kekerasan setelah laku panas austenisasi

3. Pengamatan struktur mikro. Pengamatan mikroskopis ini untuk mengamati tipe struktur mikro yang terbentuk setelah laku panas austenisasi.

4. Adapun tahapan proses yang dilakukan pada penelitian ini meliputi:

a. Bahan baku material baja karbon ASTM A-

36 sebelum dilakukan proses Austenisasi dengan pendinginan media tungku, udara, air dan oli dilakukan pengujian yang meliputi, komposisi kimia, pengujian kekerasan, kekuatan tarik dan struktur mikro b. Sampel material baja karbon baja karbon ASTM A-36 dengan 5 sampel, dimana satu sampel tanpa perlakuan sedangkan empat sampel lainnya di dilakukan Austenisasi (laku panas) pada temperatur $900^{\circ} \mathrm{C}$, di dalam muffle furnace, setelah temperatur yang diinginkan tercapai selanjutnya dilakukan penahanan temperatur masingmasing sampel selama 60 menit.

c. Kemudian masing-masing dari sampel yang telah dipanaskan pada temperatur $900 \mathrm{oC}$, dan penahanan waktu masing-masing 60 menit, selanjutnya dilakukan pendinginan dengan media tungku, air, udara dan oli. Masing-masing sampel yang telah dilakukan pendinginan kemudian dilakukan pengujian yang meliputi: kekerasan, kuat tarik dan struktur mikro.

\section{Pengambilan Sampel Uji Tarik dan Regangan}

Plat baja spesifikasi ASTM A36, tebal $2 \mathrm{~cm}$ dipotong, untuk pembuatan spesimen uji tarik. Bentuk spesimen adalah irisan plat, kemudian spesimen dibubut, dimensi dan ukuran berdasarkan standar JIS.

\section{Pengerjaan Laku Panas Austenisasi}

Pengerjaan austenisasi, spesimen dipanasi di dalam tungku pada suhu $900^{\circ} \mathrm{C}$ selama 1 jam. Penentuan waktu penahanan suhu ini karena dimensi spesimen relatif kecil (diameter $2 \mathrm{~cm}$ ), sedemikian hingga dalam waktu tersebut seluruh dimensi menerima panas merata. Agar supaya permukaan spesimen tidak teroksidasi selama dipanasi, semua spesimen dengan arang cangkang kelapa diletakkan di dalam wadah.

\section{Pengujian Kekerasan (Hardness Test)}

Pengujian kekerasan adalah untuk mengetahui kekerasan dari suatu material, adapun pengujian kekerasan dari material baja karbon ASTM A-36 dilakukan terhadap sampel awal atau sebelum dilakukan proses austenisasi dan proses pendinginan, serta juga terhadap sampel setelah dilakukan proses austenisasi dan proses pendinginan.

Kekerasan suatu logam perlu diketahui untuk mengetahui sifat mekanis dari logam tersebut. Kekerasan dapat diketahui melalui percobaan dengan cara mekanis statis yang meliputi cara Brinell, Vikers, Rockwell dan Iain-lain. 


\section{a. Kekerasan Brinell}

Dalam pengujian brinell, luas penampang benda uji yang mengalami tekanan dari indentor, di presentasikan melalui persamaan:

$$
B H N=\frac{P}{A}\left(\mathrm{~kg} / \mathrm{mm}^{2}\right)
$$

Kekerasan dinyatakan dengan $1 \mathrm{HB}$ ( $B H N$, Brinell Hardness Number) yaitu beban tekan P (kg), dibagi luas tapak tekan yang berbentuk bidang bola dan dinyatakan dengan A (mm2).

Untuk pengujian brinell di gunakan indentor berbentuk bola baja yang dibuat dari baja yang telah dikeraskan. Beban yang di berikan adalah antara 500-3000 Kg. Identor bola baja yang di berikan tersebut dapat di lihat pada gambar 30. di bawah ini.

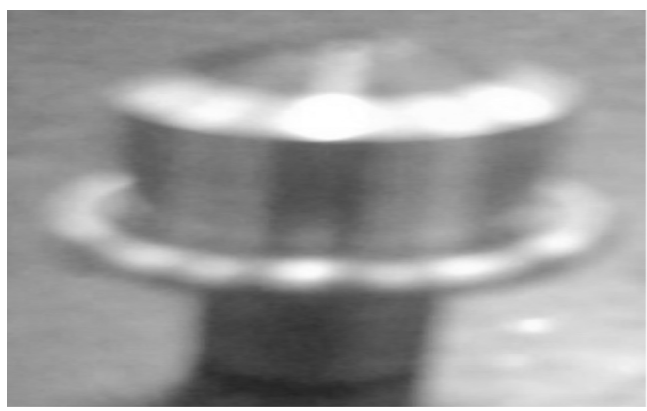

Gambar 30. Identor bola baja (Stell ball)

Dengan demikian luas penampang dari bidang bola adalah:

A = luas bangunan yang berbentuk bidang bola, maka rumus menjadi:

$A=(\pi \cdot D / 2) \cdot\left(D-\sqrt{\left(D^{2}-d^{2}\right)}\right)(\mathrm{mm} 2)$

Dimana:

$\mathrm{D} \quad=$ Diameter bola indentor $(\mathrm{mm})$

$\mathrm{d}=$ Diameter bekas penekanan $(\mathrm{mm})$

Sehingga,

$$
B H N=\frac{P}{(\pi \cdot D / 2) \cdot\left(D-\sqrt{\left(D^{2}-d^{2}\right)}\right.}\left(\mathrm{kg} / \mathrm{mm}^{2}\right)
$$

Dimana:

BHN = Nilai kekerasan brinell $(\mathrm{kg} / \mathrm{mm} 2)$

$\mathrm{P}=$ Beban indentasi $(\mathrm{kg})$

Perbandingan antara beban penekanan terhadap luas indentasi memberikan harga kekerasan brinell. Logam-logam dengan kekuatan tarik yang tinggi biasanya mempunyai kekerasan yang tinggi pula.
Gambar 31. menunjukkan skema dari pembebanan yang di lakukan dalam uji kekerasan brinell.

Tabel 1 Standar ketebalan bahan untuk pengujian kekerasaan

\begin{tabular}{|c|c|c|c|}
\hline \multirow{2}{*}{$\begin{array}{l}\text { Thickness } \\
\text { of } \\
\text { specimen } \\
\text { (mm) }\end{array}$} & \multicolumn{3}{|c|}{$\begin{array}{l}\text { Minimun Brinell Hardness for which } \\
\text { A brinell test may safety be made }\end{array}$} \\
\hline & $\begin{array}{c}500 \mathrm{~kg} \\
\text { load }\end{array}$ & $1500 \mathrm{~kg}$ load & $300 \mathrm{~kg}$ load \\
\hline 2 & 79 & 238 & 476 \\
\hline$\overline{4}$ & 40 & 119 & 238 \\
\hline 6 & 26 & 79 & 159 \\
\hline 8 & 20 & 60 & 119 \\
\hline 10 & 16 & 48 & 95 \\
\hline
\end{tabular}
brinell.

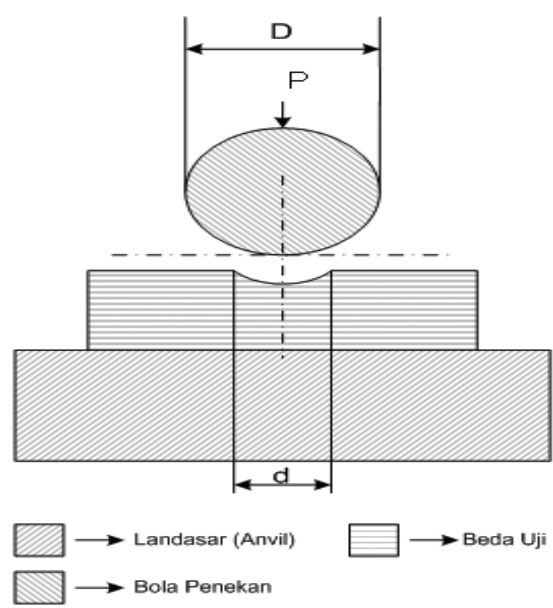

Gambar 31. Skema pengujian kekerasan brinell.

\section{b. Kekerasan Rockwel}

Pada penelitian ini digunakan pengujian kekerasan dengan metoda rockwell. Uji kekerasan rockwell berdasarkan pada pengukuran kedalaman penetrasi dari indentor. Untuk mengukur kekerasan material yang keras digunakan indentor berbentuk kerucut intan dengan sudut puncak $120^{\circ}$ (diamond Brale). Sedangkan untuk mengukur kekerasan material yang lebih lunak digunakan bola baja dengan ukuran 1,6 $\mathrm{mm}$ dan 12,7 $\mathrm{mm}$.

Pada uji kekerasan Rockwell ini terdapat beberapa skala yang dibedakan berdasarkan indentor dan beban yang digunakan untuk mengindentasi material. Masing-masing skala ini dapat dikonversikan satu dengan yang lainnya, berdasarkan Standart ASTM E-40. Dari uji kekerasan rockwell ini akan diperoleh harga kekerasan (RHN), yang dapat dikonversikan lagi menjadi kekuatan tarik maksimum (ultimate) dari material tersebut. Kekuatan tarik maksimum tersebut dapat diperoleh dengan menggunakan persamaan: 


$$
\begin{aligned}
\sigma_{u} & =3,45 \times(B H N),[\mathrm{Mpa}] \\
\sigma_{u} & =0,5 \times(B H N),[k s i]
\end{aligned}
$$

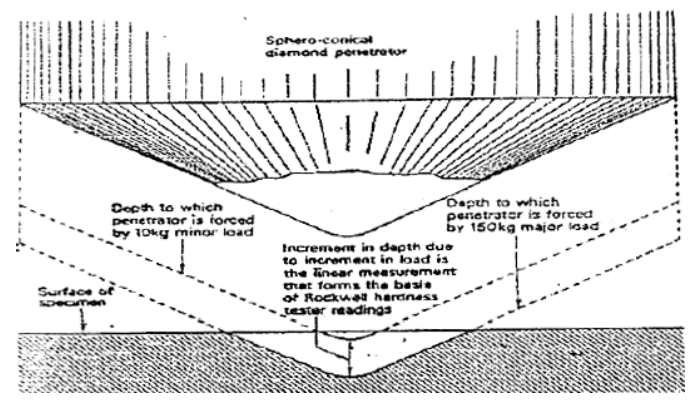

Gambar 32. Mekanisme uji kekerasan metoda rockwell.

\section{c. Kekerasan Vickers}

Pengukuran secara vickers dilakukan dengan penekanan oleh intan berbentuk piramida bersudut puncak $136^{\circ}$. Karena bentuk penumbuknya pyramid, maka pengujian ini sering dinamakan uji kekerasan piramida intan. Angka kekerasan piramida intan (DPH), atau angka kekerasan Vikers (VHN atau VPH), didefinisikan sebagai beban dibagi luas permukaan lekukan.

VHN dapat ditentukan dari persamaan berikut:

$$
\mathrm{VHN}=\frac{2 P \sin (\theta / 2)}{L^{2}}=\frac{1.854 P}{L^{2}}
$$

Dimana $\mathrm{P}=$ beban yang diterapkan, $\mathrm{kg}$

$\mathrm{L}=$ Panjang diagonal rata-rata, $\mathrm{mm}$

$\varnothing=$ sudut antara permukaan intan yang berlawanan $=136^{\circ}$

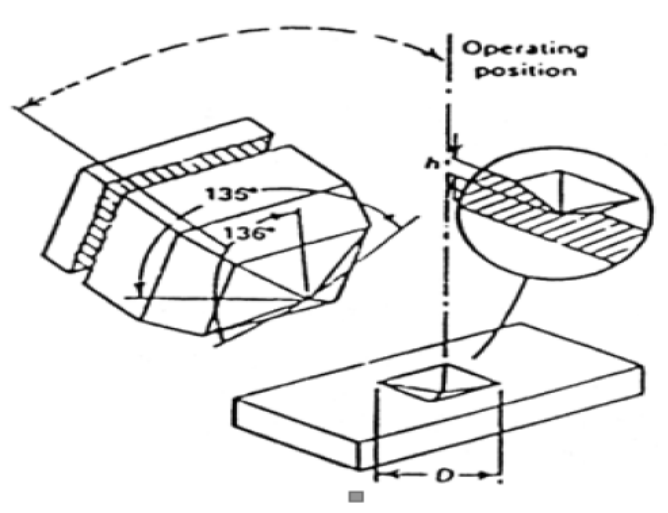

Gambar 33. Mekanisme uji kekerasan vickers.

\section{Pengujian Struktur Mikro}

Struktur mikro di uji dengan menggunakan alat metalografi. Adapun pengamatan struktur mikro dilakukan dengan mikroskop optic metalografi, adapun peralatannya seperti tertera pada gambar 33. Pengamatan struktur mikro ini bertujuan untuk melihat besar butir dan melihat fasa yang terbentuk.

\section{HASIL DAN PEMBAHASAN}

Hasil Analisa Komposisi Kimia Material Baja

Hasil analisa komposisi kimia ditunjukkan pada tabel 2 di bawah ini

Tabel 2 Komposisi kimia baja standar ASTM A36.

\begin{tabular}{|c|c|c|c|c|}
\hline $\begin{array}{c}\mathrm{C} \\
(\%)\end{array}$ & $\begin{array}{c}\mathrm{Si} \\
(\%)\end{array}$ & $\begin{array}{c}\mathrm{S} \\
(\%)\end{array}$ & $\begin{array}{c}\mathrm{P} \\
(\%)\end{array}$ & $\begin{array}{c}\mathrm{Mn} \\
(\%)\end{array}$ \\
\hline 0,26 & 0,3 & 0,04 & 0,04 & 1,4 \\
\hline
\end{tabular}

Dari tabel 2 di atas ditunjukkan bahwa material baja termasuk tipe baja karbon. Karena kandungan unsur-unsur lain seperti $\mathrm{Cr}, \mathrm{Ni}$, dan Mo tidak ada, hanya saja kandungan Mn $(1,4 \%)$ relatif tinggi jika dibandingkan dengan baja korbon konvensionil (kandungan Mn sekitar 0,5\% - 0,7\%). Tipe baja karbon ini, sifat mekanik ditentukan oleh jumlah kandungan karbon. Kandungan karbon $0,26 \%$ sehingga termasuk golongan baja karbon rendah.

\section{Hasil Uji Tegangan Tarik dan Regangan}

Plat baja Gambar 34 dipotong untuk spesimen uji tarik, jumlah spesimen adalah lima buah. Spesimen untuk diuji tarik berdasarkan standart JIS seperti yang ditunjukkan pada Gambar 34 .

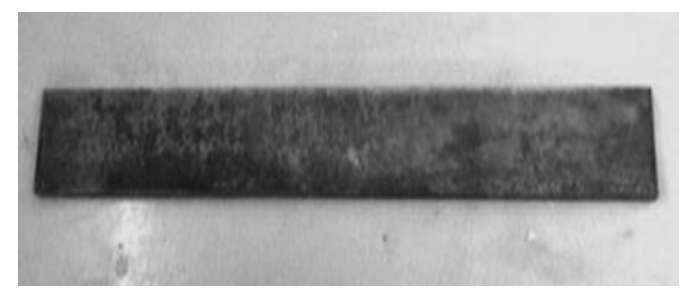

Gambar 34 Plat baja tebal yang diuji, tebal $2 \mathrm{~cm}$.

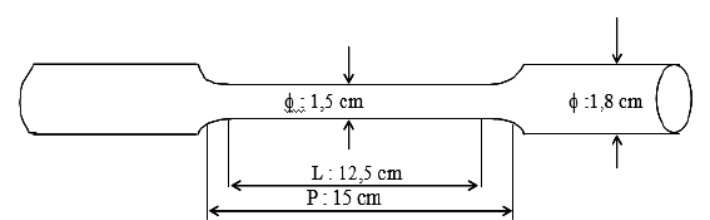

Gambar 35 Skematis spesimen uji tarik berdasarkan standar JIS.

Pembuatan spesimen uji tarik berdasarkan standar Gambar 35 dilakukan melalui pengerjaan masining (bubut). Hasil pengerjaan masining ditunjukkan pada Gambar 36. 


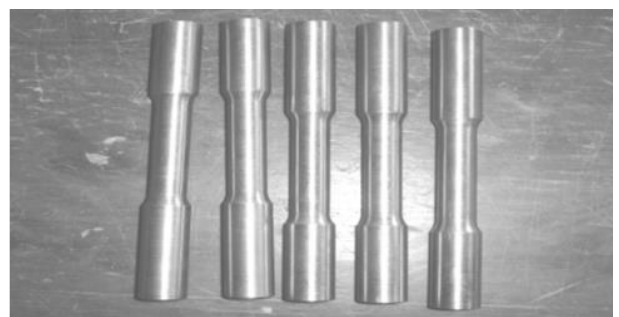

Gambar 36 Hasil masining lima buah spesimen uji tarik. Diameter bagian atas $1,8 \mathrm{~cm}$. Diameter bagian tengah yang ditarik $1,5 \mathrm{~cm}$.

Lima buah spesimen diambil empat buah, kemudian keempat buah spesimen diaustenisasi pada suhu $900{ }^{\circ} \mathrm{C}$ selama 1 jam. Kemudian masingmasing spesimen didinginkan dengan kecepatan pendinginan berbeda di dalam media tungku, udara, oli dan air. Hasil percobaan setelah laku panas austenisasi ditunjukkan pada Gambar 37.

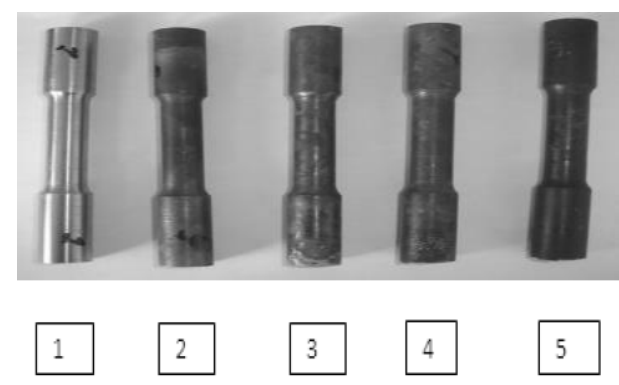

Gambar 37 Spesimen setelah laku panas.

Keterangan gambar:

1. Spesimen awal

2. Pendinginan tungku

3. Pendinginan udara

4. Pendingan celup oli

5. Pendinginan celup air.

Spesimen setelah laku panas tersebut di atas dilakukan uji tarik. Hasil patahan uji tarik ditunjukkan pada Gambar 38.

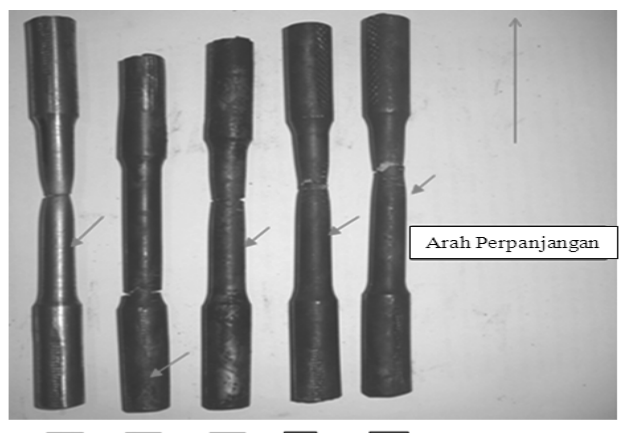

Gambar 38 Patahan spesimen setelah uji tarik. Tanda panah:
Penurunan luas penampang lintang Keterangan gambar:

1. Pendinginan tungku

2. Pendinginan udara

3. Pendinginan celup oli

4. Pendinginan celup air

5. Spesimen awal.

Dari hasil pengamatan visual seperti pada Gambar 38 menunjukkan bahwa spesimen setelah uji tarik, kalau dibandingkan dengan spesimen setelah laku panas (Gambar 37) mengalami perbedaan panjang yang berbeda. Spesimen melalui pendinginan tungku menjadi kemuluran paling panjang. Sementara itu spesimen pendinginan celup air paling pendek. Hal ini berarti pada setiap perbedaan jenis pendinginan mempunyai sifat kemuluran (elongasi) yang berbeda. Demikian juga pengamatan pada posisi patahan tampak luas penampang lintang yang berbeda (tanda panah).

Tabel 3 Data uji tarik dan regangan pada spesimen ASTM A-36 dengan kecepatan pendinginan yang berbeda. Selanjutnya dari data Tabel 3 dibuat grafik hubungan antara kecepatan pendinginan dengan kekuatan tarik dan elongasi seperti yang ditunjukkan pada Gambar 39.

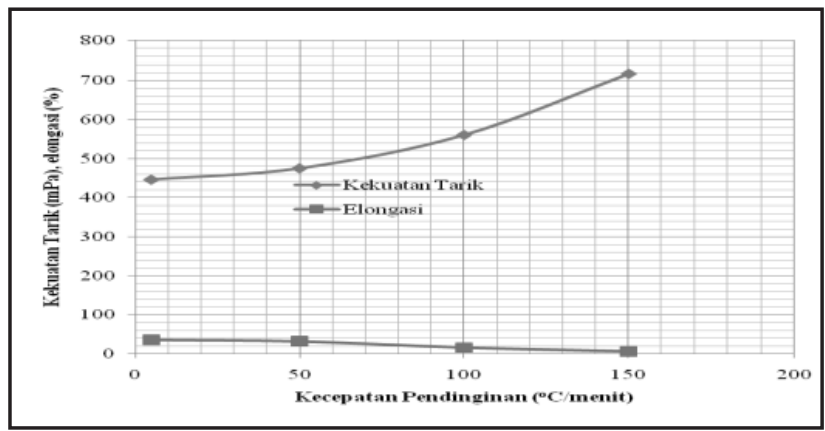

Gambar 39. Hubungan antara kecepatan pendinginan dan kekuatan tarik, elongasi.

Kurva grafik Gambar 39 menunjukkan kecepatan pendinginan berpengaruh terhadap sifat mekanik kekuatan tarik dan elongasi. Peningkatan kecepatan pendinginan diikuti dengan peningkatan kekuatan dari 445,9 $\mathrm{MPa}$ sampai tinggi hingga $717,3 \mathrm{MPa}$ Sebaliknya peningkatan kecepatan pendinginan diikuti dengan penurunan nilai elongasi yang sangat rendah $(6 \%)$. Jadi kurva grafik hubungan antara kecepatan pendinginan dan kekuatan tarik, elongasi tampak berlawanan. Walaupun melalui media celup air kekuatan tariknya tinggi, karena elongasinya rendah, maka 
logam baja mempunyai sifat getas. Sifat getas ditunjukkan tidak adanya penurunan luas penampang lintang (Gambar 39) dan tidak tampak adanya kurva deformasi plastis.

\section{Hasil Uji Kekerasan Brinnel}

Uji kekerasan brinnel terhadap masingmasing spesimen dilakukan 5 kali pengukuran. Data pengukuran ditunjukkan pada lapiran. Nilai rata-rata uji kekerasan pada setiap spesimen ditunjukkan pada Tabel 3.

Tabel 3. Hasil uji kekerasan rata-rata spesimen ASTM A36.

\begin{tabular}{|l|c|c|}
\hline $\begin{array}{c}\text { Jenis media } \\
\text { pendingin }\end{array}$ & $\begin{array}{c}\text { Kecepatan } \\
\text { pendinginan } \\
\left({ }^{\circ} \mathrm{C} / \text { menit }\right)\end{array}$ & $\begin{array}{c}\text { Kekerasan } \\
(\mathrm{Brinnel}) \\
\left(\mathrm{Kg} / \mathrm{mm}^{2}\right)\end{array}$ \\
\hline Tungku & 5 & 124,44 \\
\hline Udara & 50 & 143.1 \\
\hline Celup oli & 100 & 182.96 \\
\hline Celup air & 150 & 370.96 \\
\hline
\end{tabular}

Dari Tabel 3. dibuat grafik hubungan antara kecepatan pendinginan dan kekerasan.

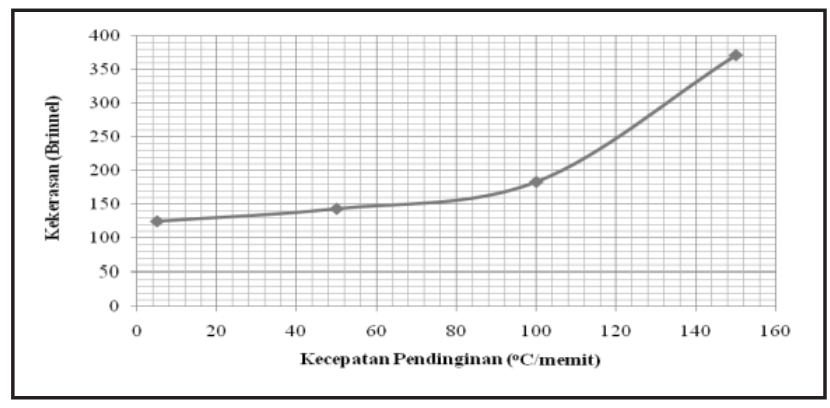

Gambar 40. Hubungan kecepatan pendinginan dan kekerasan.

Pada grafik Gambar 40. kecepatan pendinginan juga berpengaruh terhadap peningkatan kekerasan baja. Seperti sifat baja pada umumnya, peningkatan kekerasan diikuti pula oleh peningkatan kekuatan. Fakta ini ditunjukkan dari hasil percobaan, hubungan antara kekuatan dan kekerasan, seperti yang ditunjukkan pada Gambar 40, Seperti yang telah disebutkan di atas walaupun kekerasan dan kekuatan tarik tinggi, tetapi elongasinya rendah 6\% (Gambar 39). Jadi terhadap spesimen baja A-36, laku panas suhu austenisasi (900oC), dilanjutkan ke pendinginan cepat celup air, tidak membuat baja menjadi mempunyai sifat mekanik yang bagus. Hal ini disebabkan karena baja mempunyai sifat getas. Sifat getas pada pada material baja, menjadi mudah retak bila mengalami beban tarik (bebannya masih di bawah kekuatan luluh) atau kompresi mendadak (dalam kurun waktu sekitar 1/100 detik).
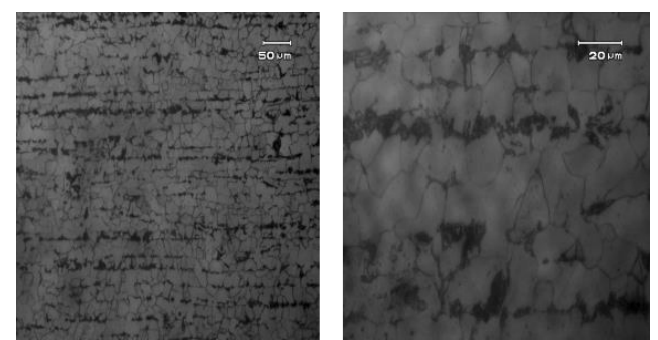

Gambar 41. Hubungan kekuatan tarik dengan kekerasan.

\section{Hasil Pengamatan Struktur Mikro}

Pengamatan struktur mikro pada masingmasing spesimen setelah austenisasi $\left(900^{\circ} \mathrm{C}\right)$ dengan media pendingin berbeda (tungku, air, oli, dan udara) ditunjukkan pada Gambar 41, sampai dengan 45. Untuk keperluan analisa struktur mikro disajikan dua foto dengan pembesaran yang berbeda, agar supaya fasa yang terbentuk lebih tampakjelas.
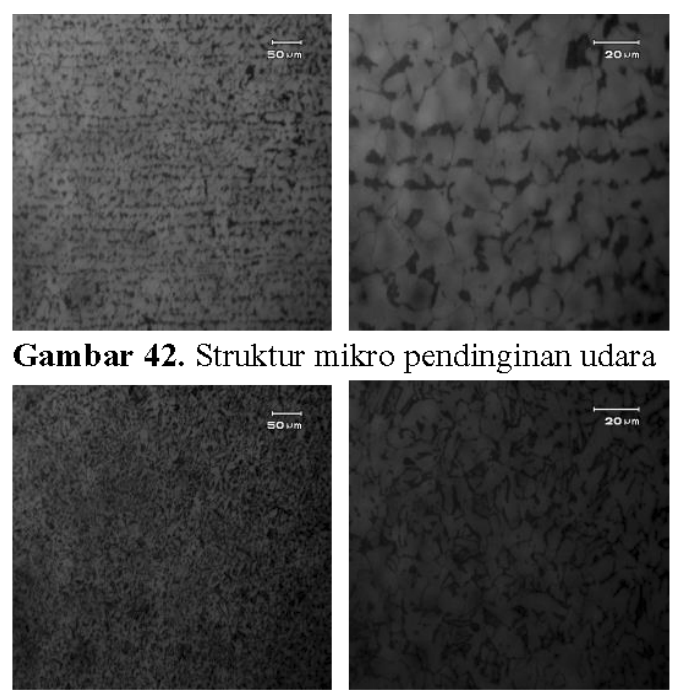

Gambar 43. Struktur mikro pendinginan oli

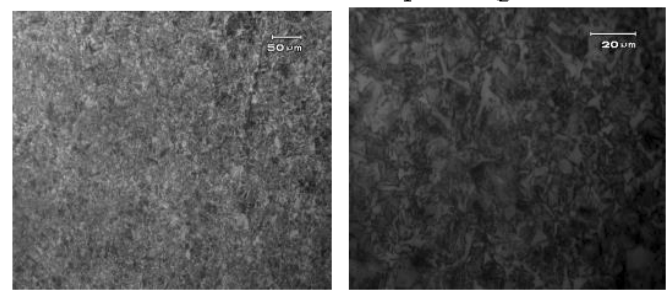

Gambar 44. Struktur mikro pendinginan celup ai
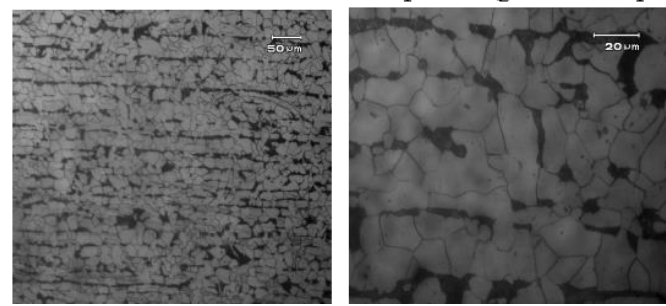

Dari pengamatan hasil pengujian dan pembahasan terhadap baja ASTM A-36 yang telah dilakukan, perlu dipilih perlakuan spesimen yang 
mempunyai peningkatan sifat mekanik dari pada bahan awal. Hasil percobaan menunjukkan bahwa perlakuan setelah austenisasi, pendinginan udara dan oli memberikan sifat mekanik yang bagus, dengan alasan sebagai berikut:

a. Kekuatan spesimen melalui pendinginan udara dan celup oli (474,9 $\mathrm{MPa}, 560,5 \mathrm{MPa})$ lebih tinggi dari pada bahan awal (423.9 MPa). Di dalam struktur mikro, peningkatan kekuatan ditunjukkan adanya distribusi perlit.

b. Spesimen mempunyai sifat tangguh, karena ke dua spesimen nilai elongasinya relatif tinggi (32\% dan 16\%). Di dalam struktur mikro, peningkatan elongasi ditunjukkan adanya butir fasa ferit sebagai matrik.

\section{KESIMPULAN}

Perlakuan austenisasi baja ASTM A-36, dengan media pendingin yang memberikan perbedaan kecepatan pendinginan dapat disimpulkan sebagai berikut:

Sifat mekanik kekuatan baja ASTM A-36 dapat ditingkatkan melalui pengerjaan austenisasi dengan media pendingin tungku, udara, celup oli, dan air.

Pengerjaan austenisasi dengan media pendingin udara dan celup oli memberikan sifat mekanik yang bagus. Disamping kekuatannya lebih tinggi dari pada bahan awal, baja masih tetap tangguh (nilai elongasi tinggi: $32 \%$ dan 16\%).

Pengerjaan austenisasi dengan media pendingin di dalam tungku, kecepatan pendinginan lambat, kekuatannya lebih rendah dari pada media pendingin udara dan celup oli.

Pengerjaan austenisasi dengan media pendingin di dalam tungku, memberikan kekuatannya (445,9 $\mathrm{MPa}$ ) sedikit lebih tinggi dari pada bahan awalnya yaitu $(423,9 \mathrm{MPa})$, serta bersifat tangguh.

Pengerjaan austenisasi dengan media pendingin di celup air, walaupun kekuatan baja meningkat tinggi (717,3 MPa), tetapi baja menjadi getas.

\section{DAFTAR PUSTAKA}

ASTM. Metal Hand Book, "Properties and Selection Iron and Steel" 9th ed, vol 1, Formely Tenth Edition Metal Hand Book, Second Printing, 1992.

Annual Book of ASTM Standard, Section
3, Metal Test Methods and Analytical Prosedures, "Metals-Mechanical Testing", Eleveted and low Temperatur Test, Metallography, Vol.03.01.

B.Zakharov, "Heat Treatment of Metals", Peace Publisher, Moscow.

George E. Dieter, "Mechanical Metallurgy", International Student Edition, Second Edition Mc.Graw-Hill Kogakusha Ltd, Tokyo, 1978.

George E. Dieter, "Work Ability Testing Techniquues", ASM, Metal Park Ohio 44073, 1984.

George Krauss, "Heat Treatment and Processing Principle", Material Park, Ohio 44073.

Herman W.pollack, "Materials Sciece and Metalurgi", Third Edition, Reston Publishing Company, Inc.

K-E Thelning, "Steel and Its Heat Treatment, Bofors Handbook, 1974.

Marder, A,R,'The Effect of Heat Treatment on The Properties", Metal Trans, Vol 12A, Sep. 1981. 